\title{
NONMARINE FACIES IN THE LATE TRIASSIC(?) TO EARLY JURASSIC HORN MOUNTAIN TUFF MEMBER OF THE TALKEETNA FORMATION, HORN MOUNTAIN, LOWER COOK INLET BASIN, ALASKA
}

\author{
David L. LePain ${ }^{1}$, Richard G. Stanley ${ }^{2}$, and Kenneth P. Helmold ${ }^{3}$
}

\section{INTRODUCTION}

The Talkeetna Formation is a prominent lithostratigraphic unit in south-central Alaska. In the Iniskin-Tuxedni area, Detterman and Hartsock (1966) divided the formation into three mappable units including, from oldest to youngest, the Marsh Creek Breccia, the Portage Creek Agglomerate, and the Horn Mountain Tuff Members. The Horn Mountain Tuff Member was thought to include rocks deposited in a nonmarine setting based on the presence of "tree stumps in an upright position" (Detterman and Hartsock, 1966, p. 19) near the top of the type section at Horn Mountain. Bull (2015) recognized possible nonmarine volcaniclastic rocks in the member during the 2014 field season in a saddle on the north side of Horn Mountain (figs. 2-1 and 2-2). The authors visited this location in 2015 and measured a short stratigraphic section to document facies, interpret depositional setting, and constrain age. This report summarizes our field observations and presents preliminary interpretations.

\section{FACIES IN THE HORN MOUNTAIN TUFF MEMBER AT HORN MOUNTAIN}

The measured section includes $45 \mathrm{~m}$ of interbedded volcaniclastic siltstone, sandstone, and granule conglomerate, and a possible air-fall tuff (fig. 2-2). Chippy, brown- to maroon-weathering, massive siltstone is the dominant facies in the section (fig. 2-3a). This facies includes scattered, irregularly shaped, centimeter-scale masses of pale-green to green-white material that resemble rhizoliths. Small ovoid-shaped patches of silty sandstone up to a few centimeters in maximum diameter are present locally in siltstone (fig. 2-3b). Wavy, slickenside striated surfaces with variable orientations in close proximity are scattered throughout the siltstone (fig. 2-3c). Brown- to maroon-weathering siltstone beds at the base of the measured section include scattered sand- and small-granule-sized crystals of white feldspar, glassy appearing grains of unknown identity, and pistachio-green altered pumice fragments (fig. 2-3d). Silicified pieces of wood up to $40 \mathrm{~cm}$ long are associated with siltstone near the top of the measured section (fig. 2-4a); a small log was observed in growth position in siltstone near the same stratigraphic level and rare fragments of poorly-preserved plant fossils are present in the same facies (fig. 2-4b).

Several bodies of medium- to very-coarse-grained, trough cross-bedded sandstone interrupt the siltstone succession and all have sharp bounding contacts (fig. 2-5a). Most of the sandstones are less than a meter thick and have tabular geometries at outcrop scale. However, two of these sand bodies that crop out in the lower to middle part of the measured section are up to $4 \mathrm{~m}$ thick and fine upward from granule conglomerate lags to coarse-grained sandstone and thin laterally, suggesting channelized geometries (fig. 2-5b). The erosion surface at the base of the lower channel-fill sand body separates it from an underlying light tan to gray-white colored, well-indurated lithology with abundant sand-sized grains floating in a fine-grained matrix that appears to be an air-fall tuff. Many of these grains appear to be flattened pumice fragments. Well-preserved plant fossils were recovered from near the base of the thick channel-fill sandstone in the middle part of the measured section (figs. 2-4c and 2-4d).

Several tabular bodies of very-poorly-sorted granule to pebble conglomerate are present in the section and two varieties are recognized. One variety of conglomerate is dominated by pumice clasts oriented parallel to bedding (figs. 2-6a and 2-6b) and the other by lithic clasts. Conglomerate beds range from less than $10 \mathrm{~cm}$ to more than $4 \mathrm{~m}$ thick and both matrix- and clast-supported textures are represented in thin and thick beds. Most beds are structureless, but widely spaced, crudely developed horizontal lamination is visible locally. A well-preserved plant fossil was found on the surface of a thin pumice clast conglomerate near the base of the section (fig. 2-4e). A conglomerate bed greater than $4 \mathrm{~m}$ thick caps the measured section (fig. 2-6c). This bed is clast-supported and comprises white, light yellow, and green-white colored pumice clasts up to $6 \mathrm{~cm}$ long that are oriented parallel to bedding and subordinate, similarly sized dark brown to black lithic clasts of unknown composition (fig. 2-6d); the matrix is poorly sorted silt and sand. The most striking aspect of this conglomerate bed is the abundance of large, silicified logs that it contains, some more than $1.5 \mathrm{~m}$ in diameter and $4 \mathrm{~m}$ in apparent length, all oriented parallel to bedding (fig. 2-6e). These logs were clearly visible during our aerial reconnaissance of the section (fig. 2-6c). The smaller silicified logs weathering out of siltstone near the top of the section (see above) come from a stratigraphic level a few meters below this log-bearing conglomerate bed.

\footnotetext{
${ }^{1}$ Alaska Division of Geological \& Geophysical Surveys, 3354 College Rd., Fairbanks, AK 99709-3707; david.lepain@alaska.gov

${ }^{2}$ U.S. Geological Survey, 345 Middlefield Rd., MS 969, Menlo Park, CA 94025

${ }^{3}$ Alaska Division of Oil and Gas, 550 W. $7^{\text {th }}$ Ave., Suite 800, Anchorage, AK 99501
} 


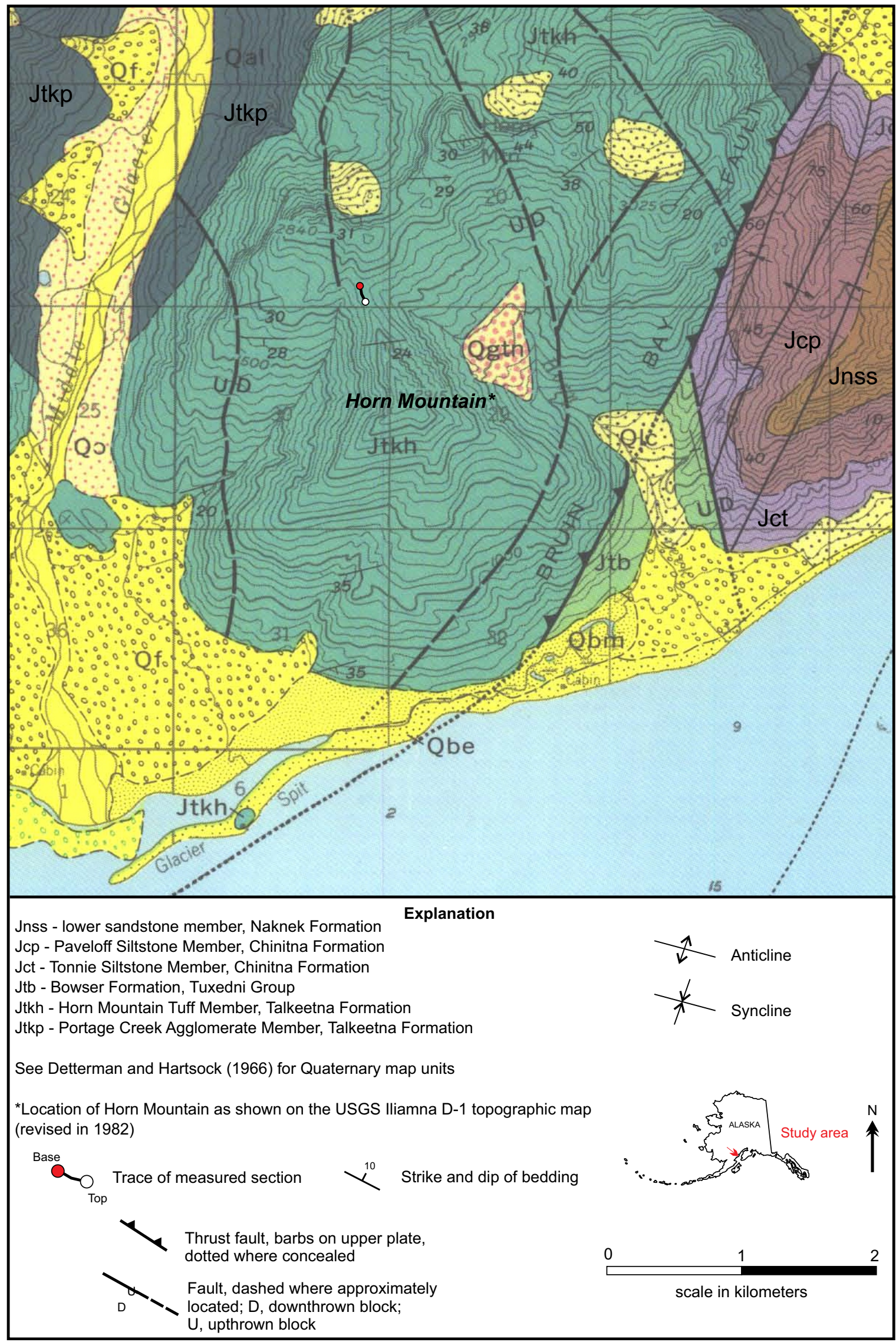

Figure 2-1. Geologic map of the Horn Mountain area, lower Cook Inlet, Alaska, showing the location of the measured section. Modified from Detterman and Hartsock (1966). Note that the location of Horn Mountain shown immediately north of Chinitna Bay corresponds to the location of the feature on the revised version of the 1958 USGS Iliamna D-1 1:63,360-scale topographic map (revised in 1982). 


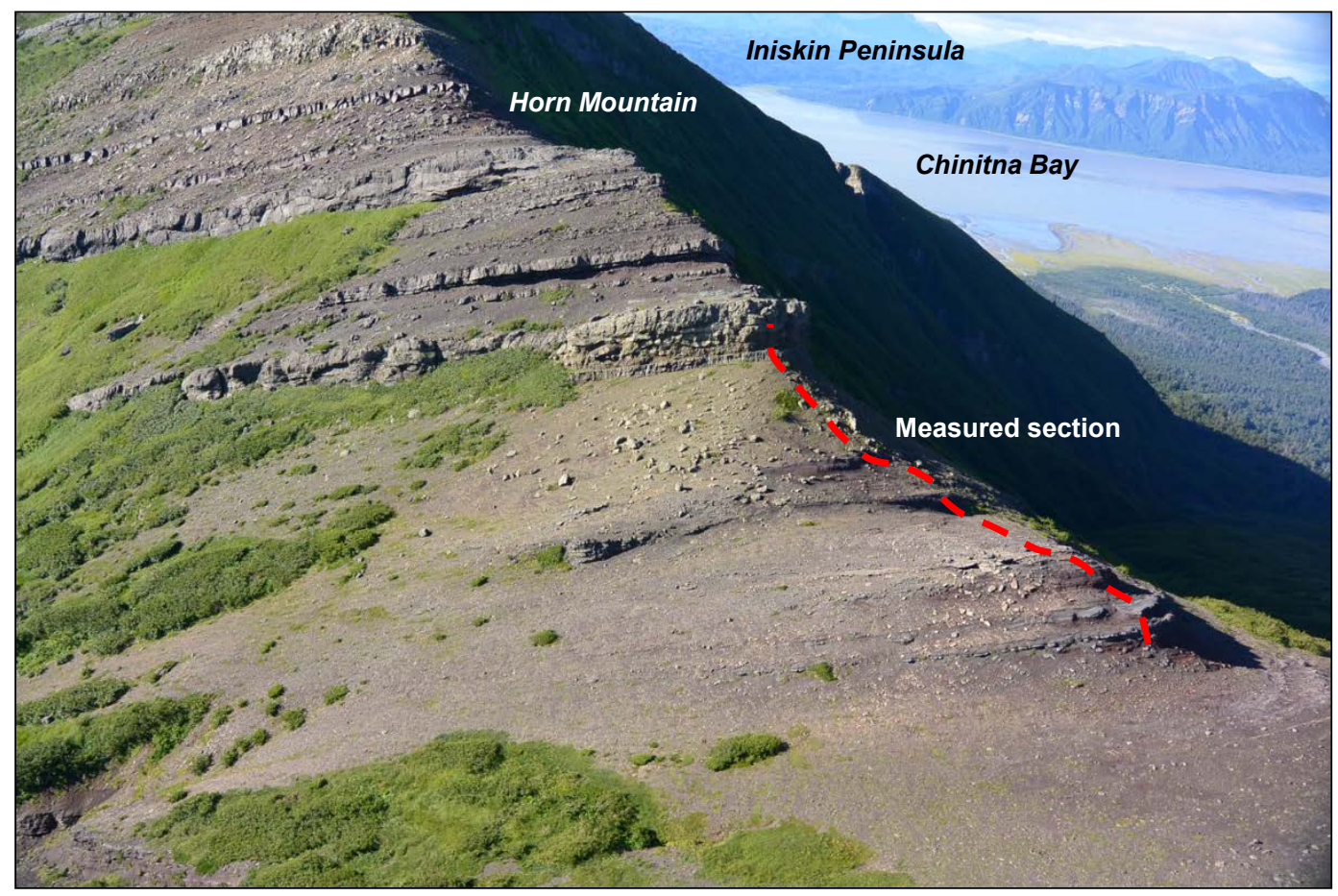

Figure 2-2. Oblique aerial photograph showing the outcrop of Horn Mountain Tuff Member addressed in this report. Note the brown- to maroon-colored strata in the measured section and that rocks of similar appearance continue above and below it. Measured section is $45 \mathrm{~m}$ thick, for sense of scale. See figure 2-1 for the location. View is toward the south.

\section{FACIES INTERPRETATION}

We interpret the succession in our measured section as the record of deposition on an alluvial plain in a volcanic setting. Siltstone strata record deposition in an overbank environment, and their brown and maroon coloration suggests an oxidized, well-drained setting. The irregularly shaped masses of pale-green and green-white material in siltstone are tentatively interpreted as cement-filled root structures. Ovoid-shaped patches of silty sand in the siltstone facies suggest mixing and destruction of thin sand beds or laminae through soil-forming process or by burrowing organisms. The irregular shape of the slickenside striated surfaces suggests a pedogenic origin, but several high-angle faults and at least one thrust fault have been mapped nearby so a tectonic origin is also possible (fig. 2-1). Small fluvial channels drained the landscape and were ultimately filled with trough-cross stratified sand upon abandonment. Hyperconcentrated flood flows and debris flows transported poorly sorted material across the landscape and deposited siltstones with floating, sand-sized clasts and conglomerates with pebble-sized pumice and lithic clasts. Smaller trees in growth position along with plant fossils suggest the alluvial setting was vegetated. The presence of logs in growth position in the highest conglomerate bed indicates that large trees were growing beyond active channel margins. Although it is unknown how representative our section is of the Horn Mountain Tuff Member overall, aerial reconnaissance in the Horn Mountain area suggests similar brown- to maroonweathering beds continue for considerable distances above and below our measured section.

\section{AGE CONSTRAINTS AND FUTURE WORK}

During the 2014 field season a palynology sample was collected from siltstone immediately below the thick conglomerate bed at the top of our measured section; it yielded a Late Triassic age assignment. It is unclear if this palynomorph assemblage reflects a stratal age or reworking from older sediments. An extensive suite of palynology samples was collected during the 2015 season from siltstones throughout our measured section to verify this age assignment; results will be published in a subsequent report. 


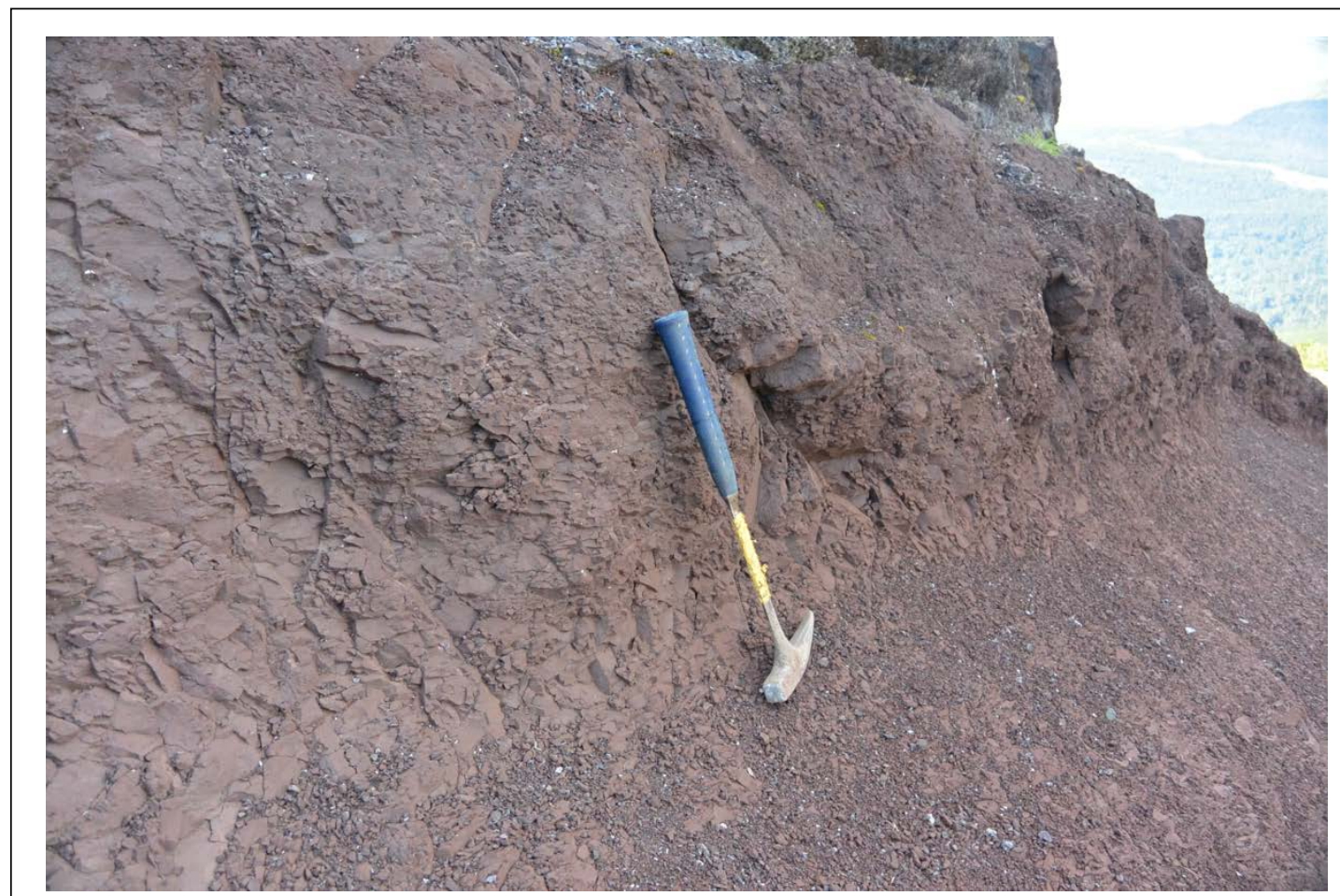

Figure 2-3a.

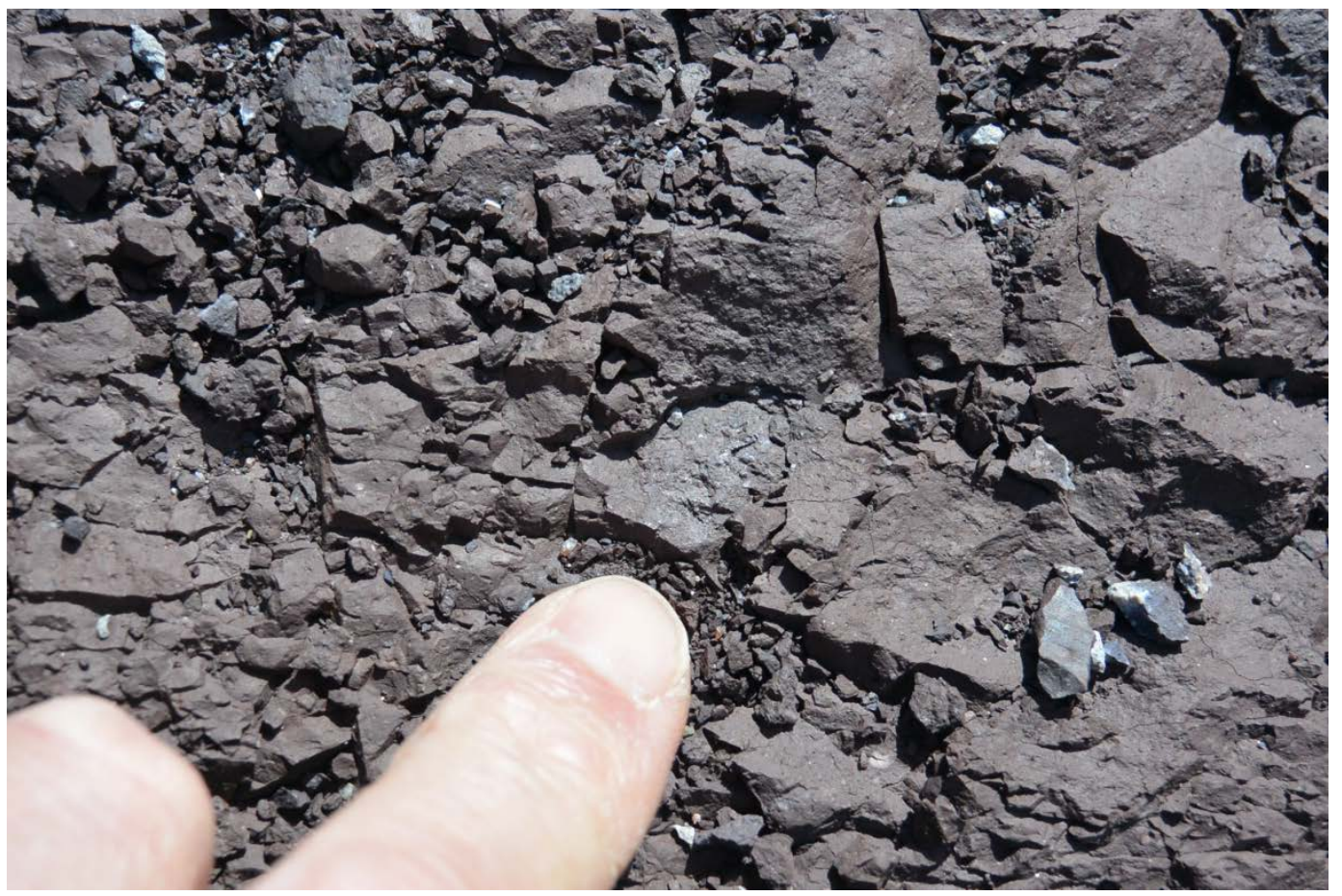

Figure 2-3b.

Figure 2-3. Selected photographs showing key features in siltstones from the study area. $\boldsymbol{a}$. Chippy weathering siltstone. Hammer is $42 \mathrm{~cm}$ long. $\boldsymbol{b}$. Chippy weathering siltstone with ovoid-shaped pocket of silty sandstone. 


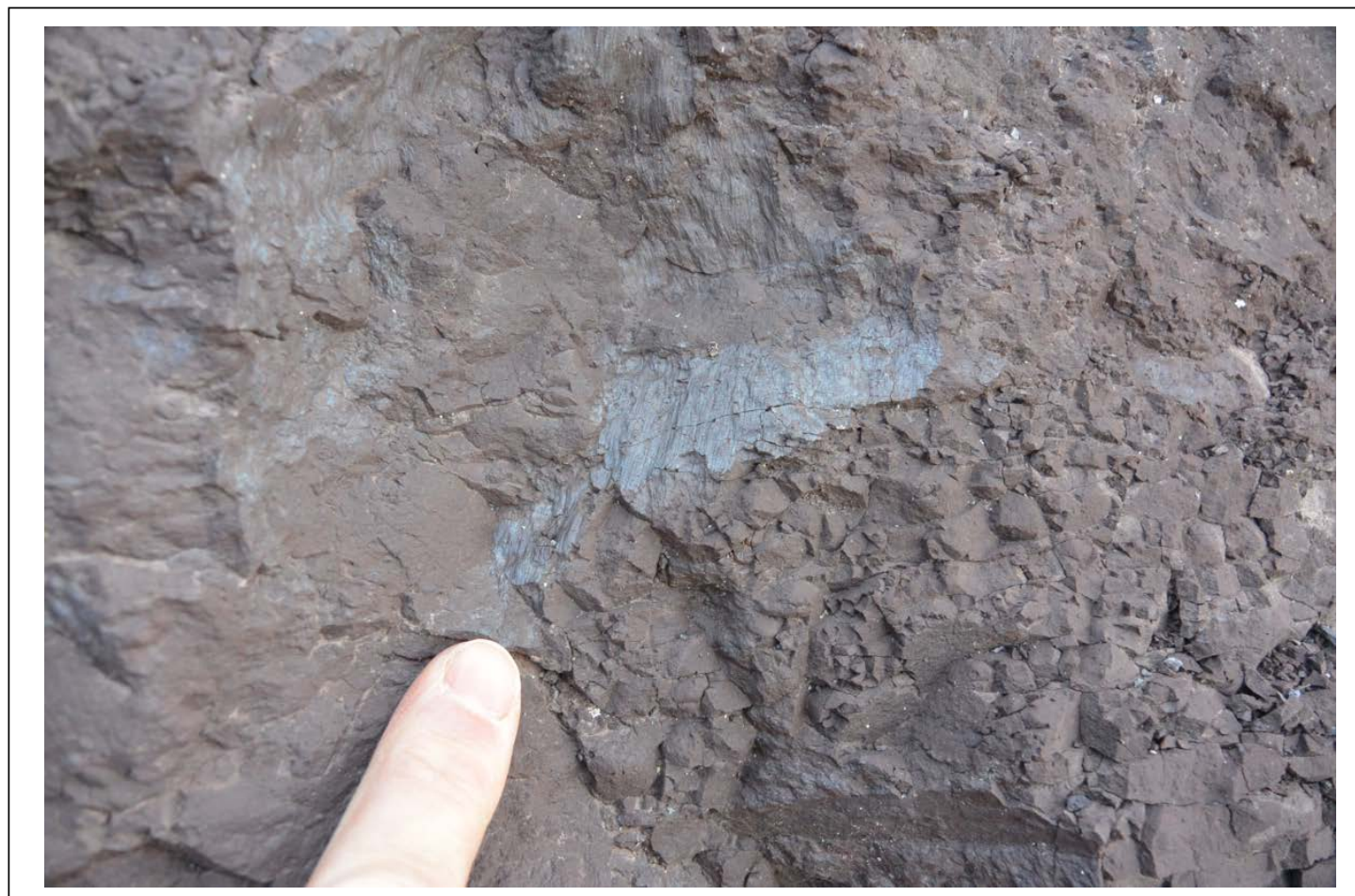

Figure 2-3c.

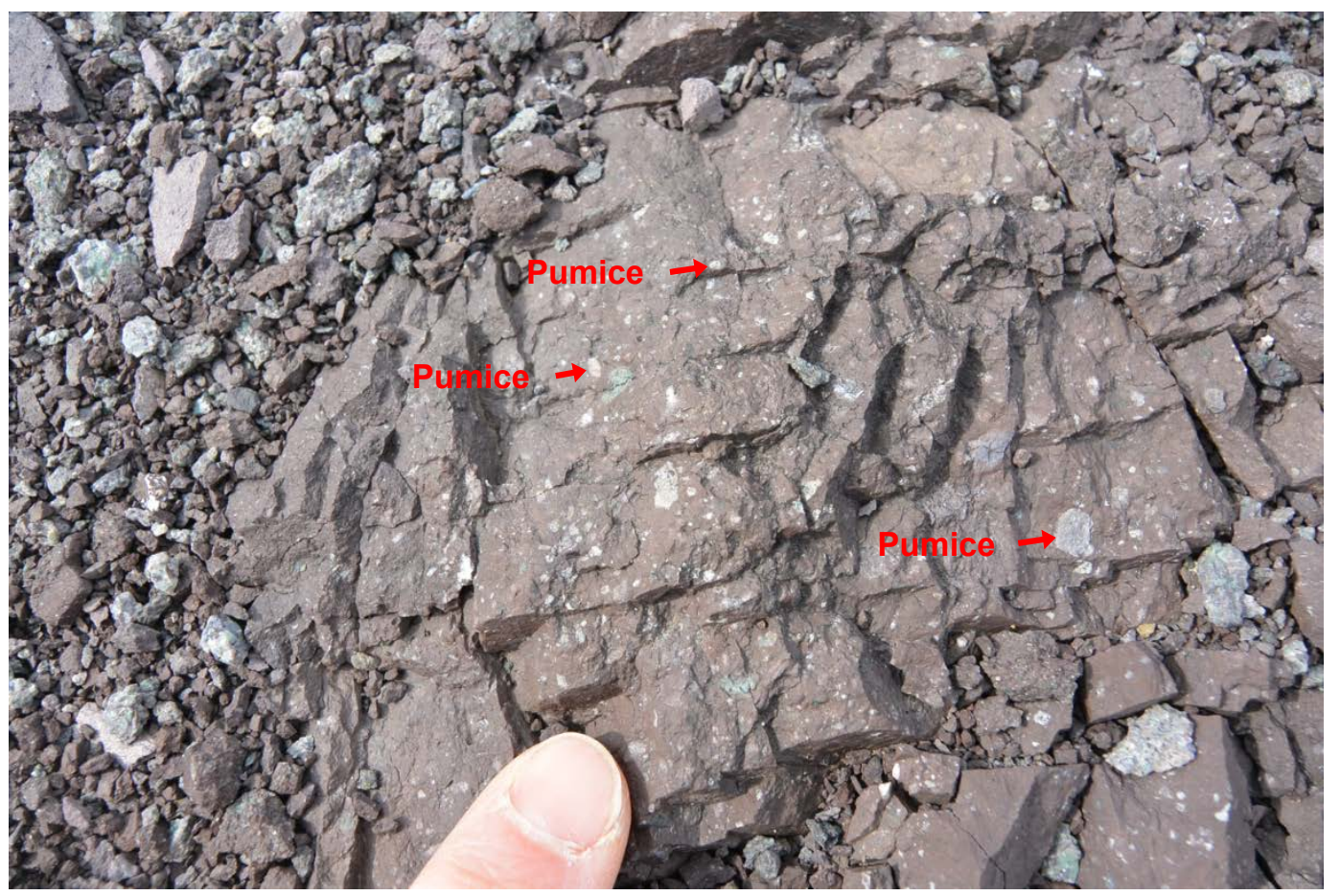

Figure 2-3d.

Figure 2-3 (cont.). Selected photographs showing key features in siltstones from the study area. c. Slickenside striae in chippy siltstone. $d$. Pumice clasts in siltstone. 


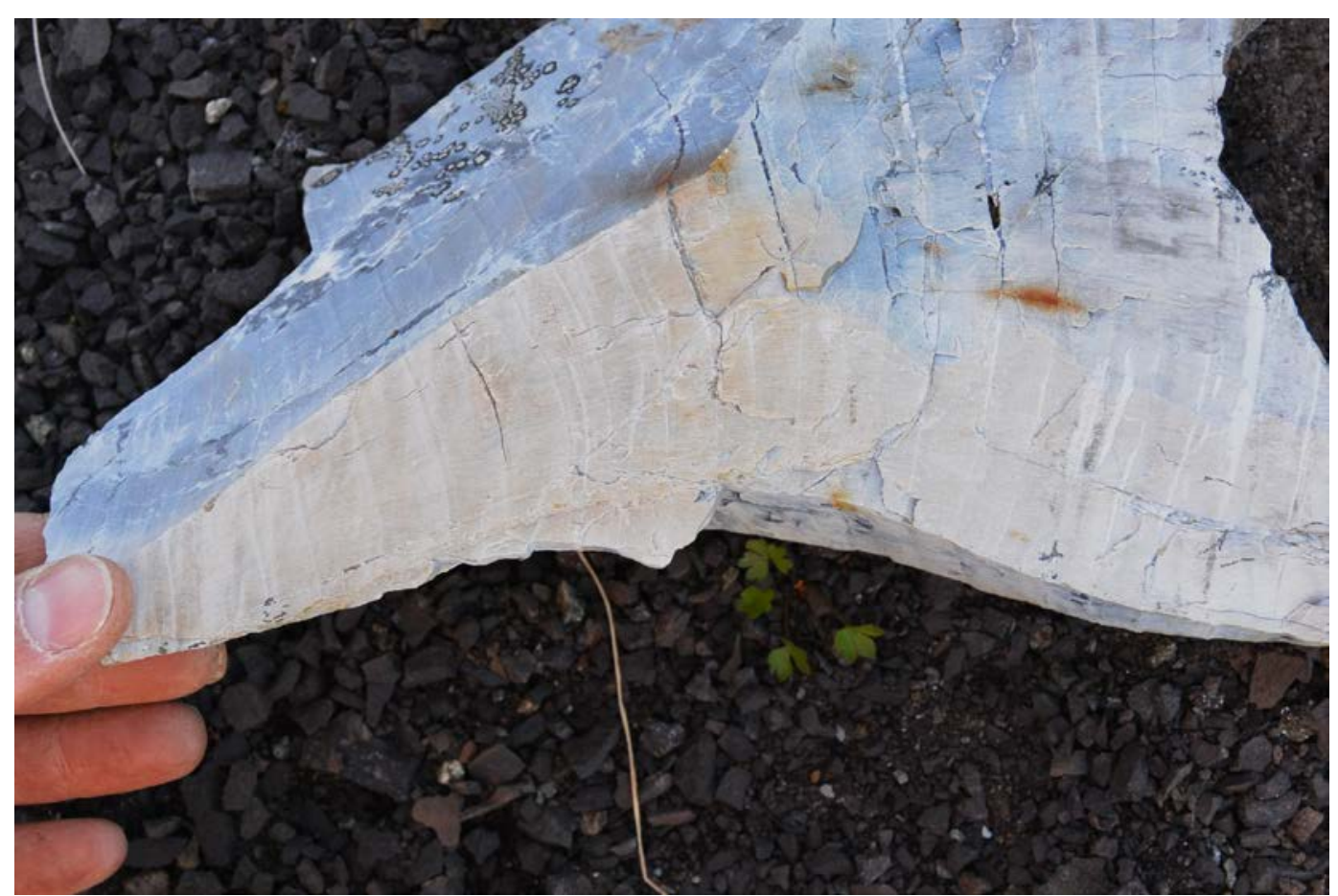

Figure 2-4a.

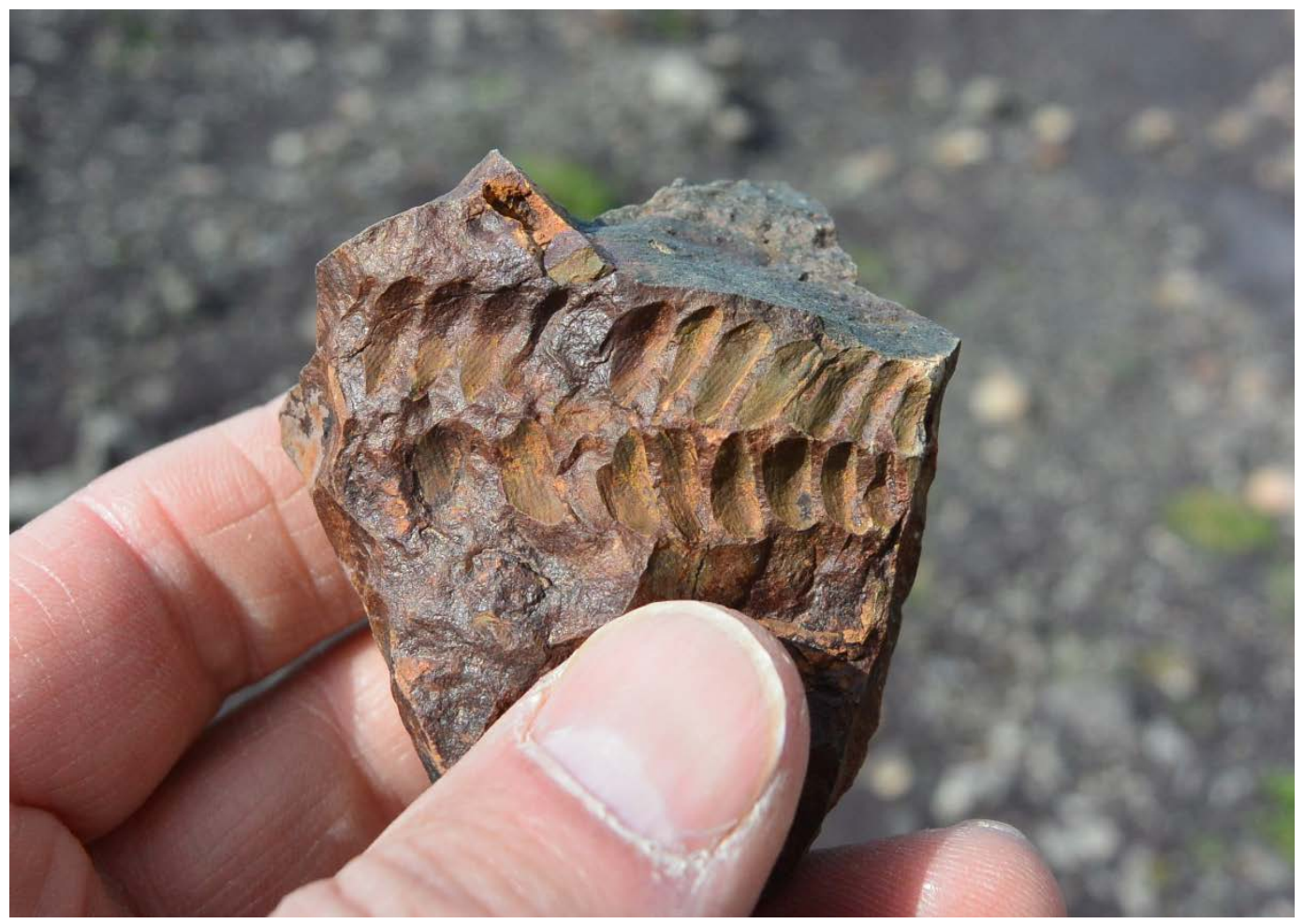

Figure $2-4 b$.

Figure 2-4. Selected photographs showing plant megafossils from the study area. a. Silicified log fragment with well-preserved woody cell structure visible on surface. Log weathered out of siltstone a few meters below the thick conglomerate bed shown in figure 2-6c. $\boldsymbol{b}$. Cone-like fossil from siltstone. 


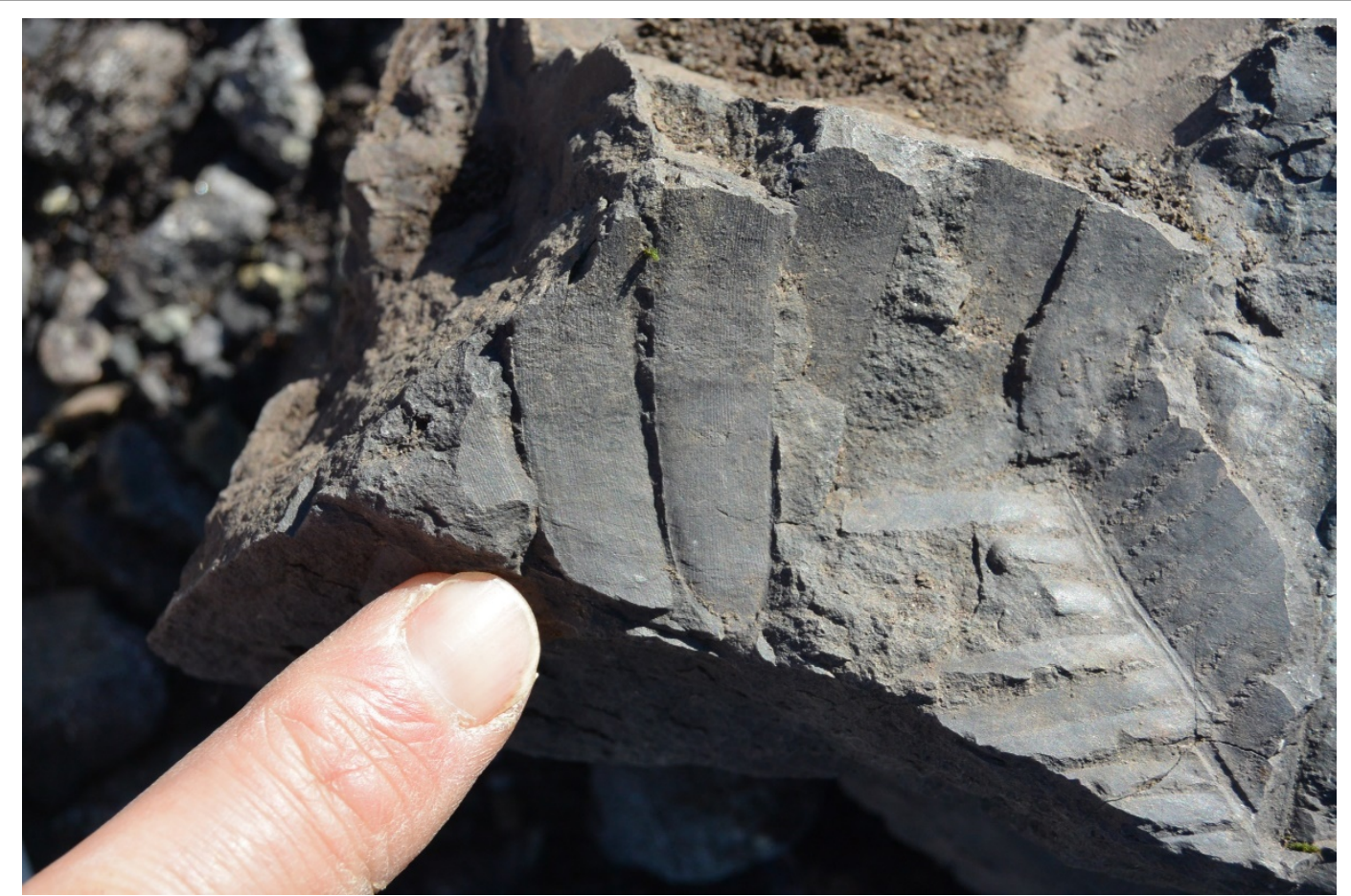

Figure 2-4c.

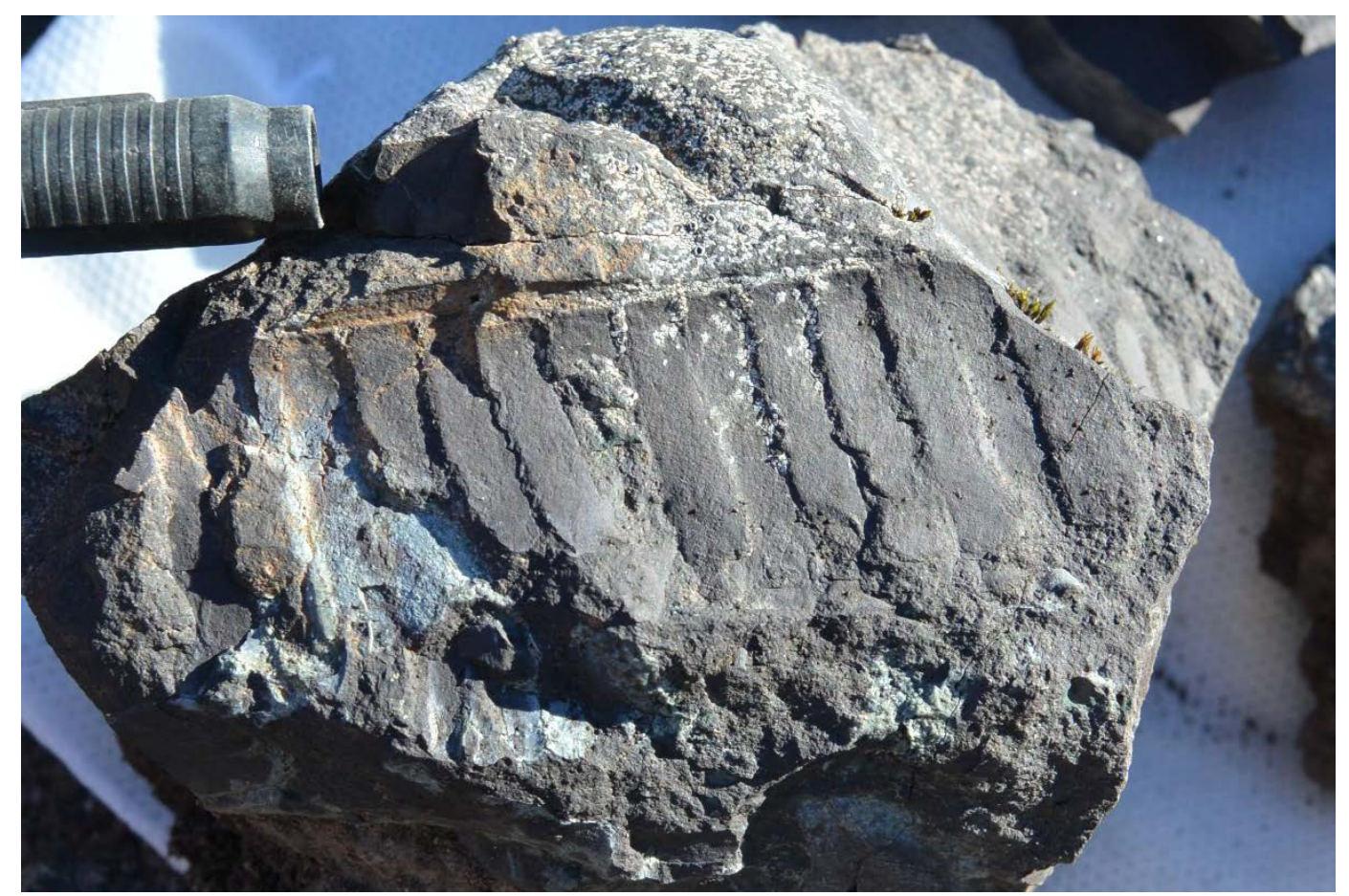

Figure 2-4d.

Figure 2-4 (cont.). Selected photographs showing plant megafossils from the study area. $\mathbf{c}-\boldsymbol{d}$. Leaf impressions in silty sandstone. Tip of eraser in $d$ is $2.0 \mathrm{~cm}$ long. 


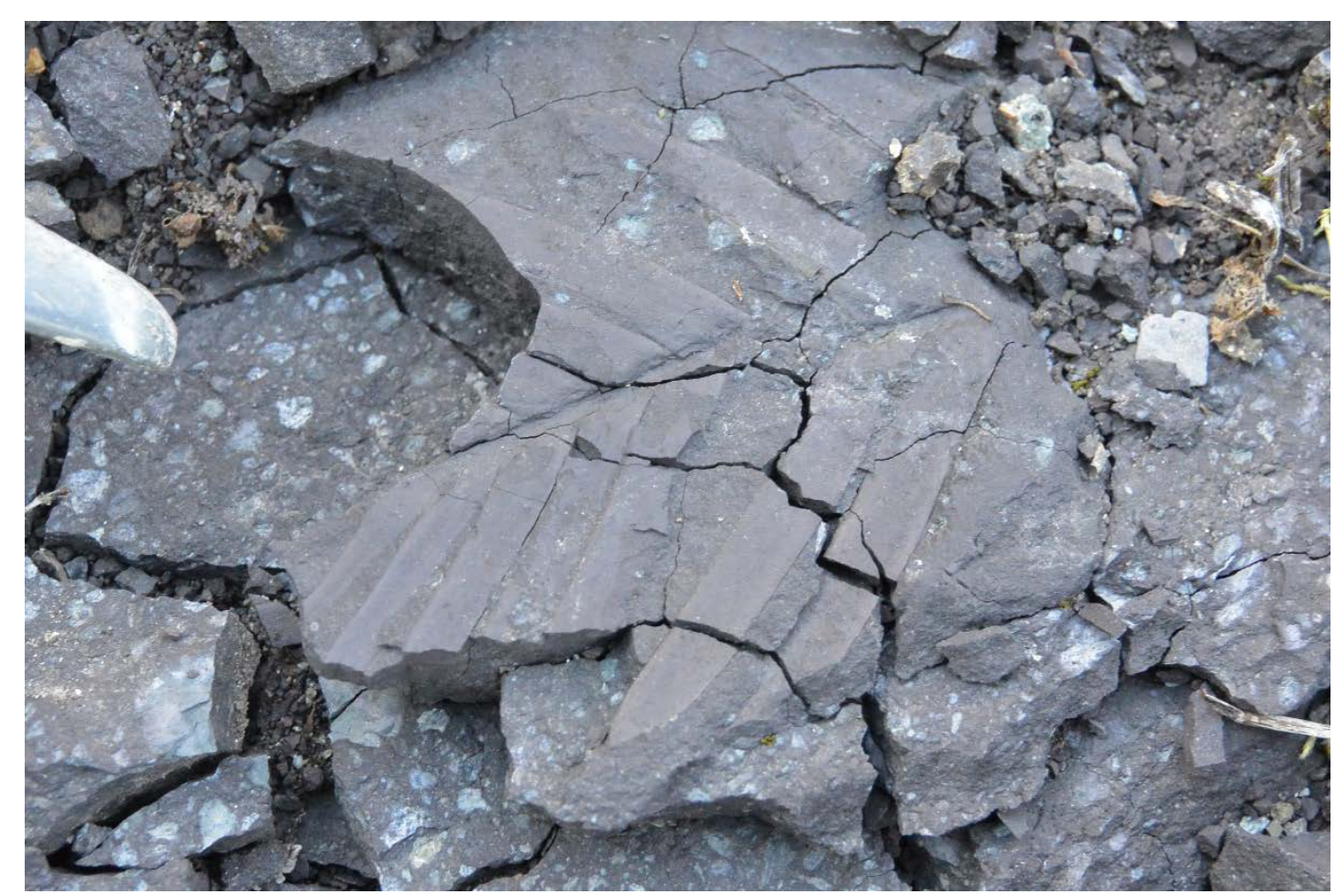

Figure 2-4e.

Figure 2-4 (cont.). Selected photographs showing plant megafossils from the study area. e. Leaf impression on surface of pumice clast conglomerate near the base of the measured section. Tip of hammer in e is $2.5 \mathrm{~cm} l o n g$. Note frond-like shape of leaves and the angle between fronds and stems in c-e. Leaves shown in $d$ are oriented nearly perpendicular to stem, whereas those in c and e meet stem at an acute angle. These differences suggest plant fossils may represent at least two different species. Fossils shown in c-e resemble Otozamites shown in Knowlton (1916, plates 79 and 81) collected from the Talkeetna Formation on the north side of the Matanuska Valley. 


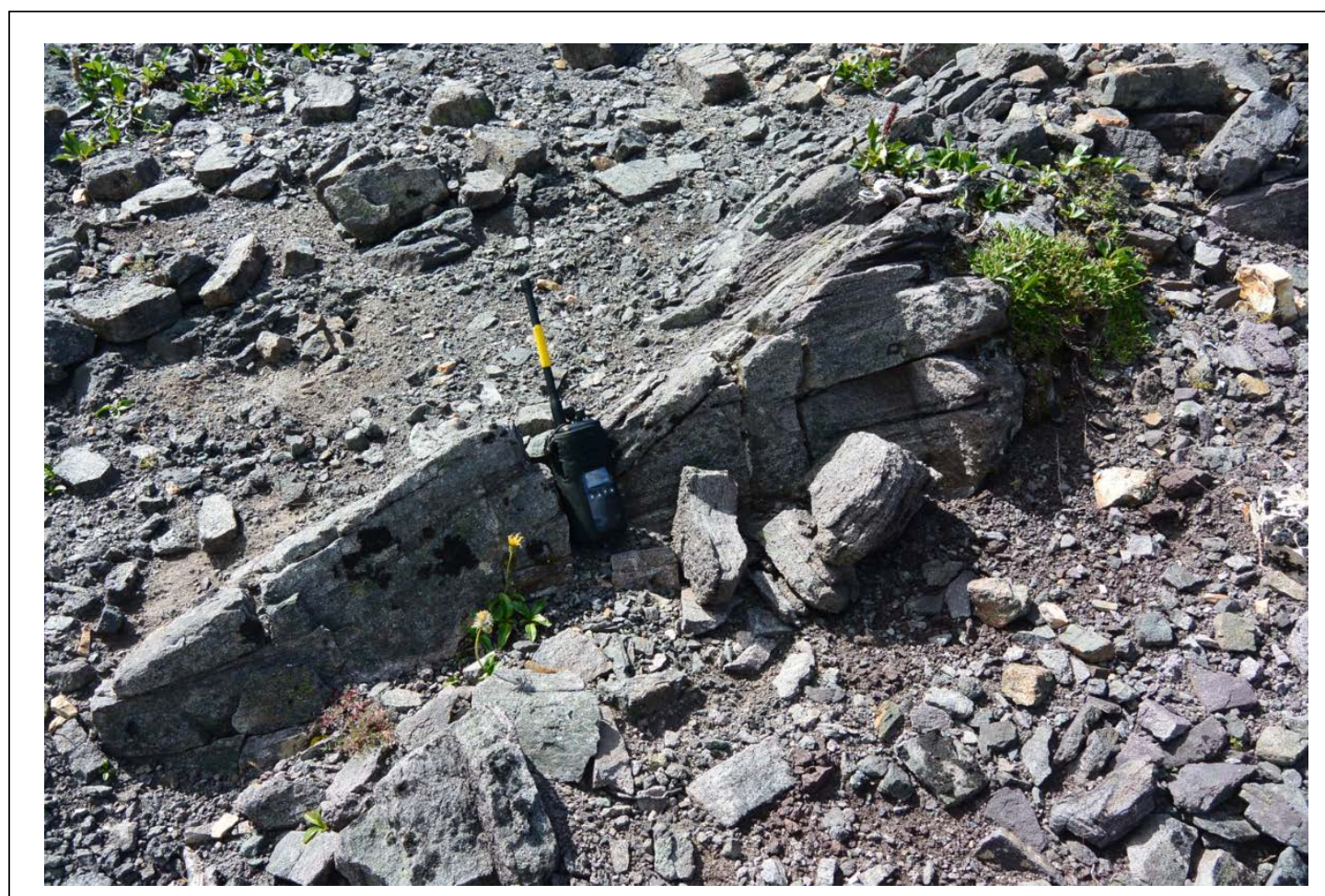

Figure 2-5a.

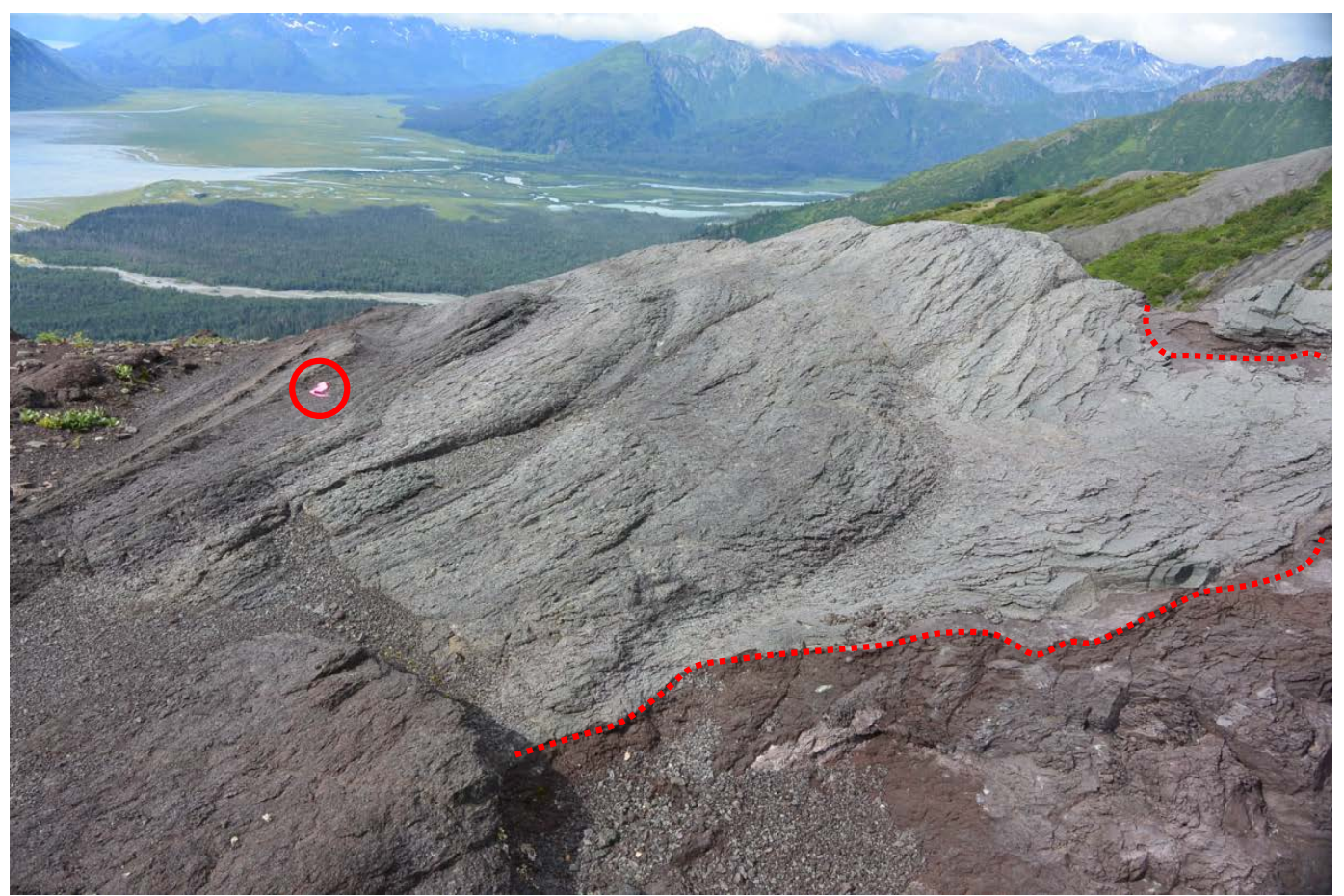

Figure 2-5b.

Figure 2-5. Selected photographs showing key features in sandstones from the study area. a. Trough cross-bedded, coarse-grained sandstone. Field radio for scale, including yellow/black antenna, is approximately $14 \mathrm{~cm}$ long. $\boldsymbol{b}$. Trough cross-bedded, very coarse-grained sandstone filling a fluvial channel. Pink flag (in red circle) is approximately $1 \mathrm{~m}$ above channel base (dotted red line). 


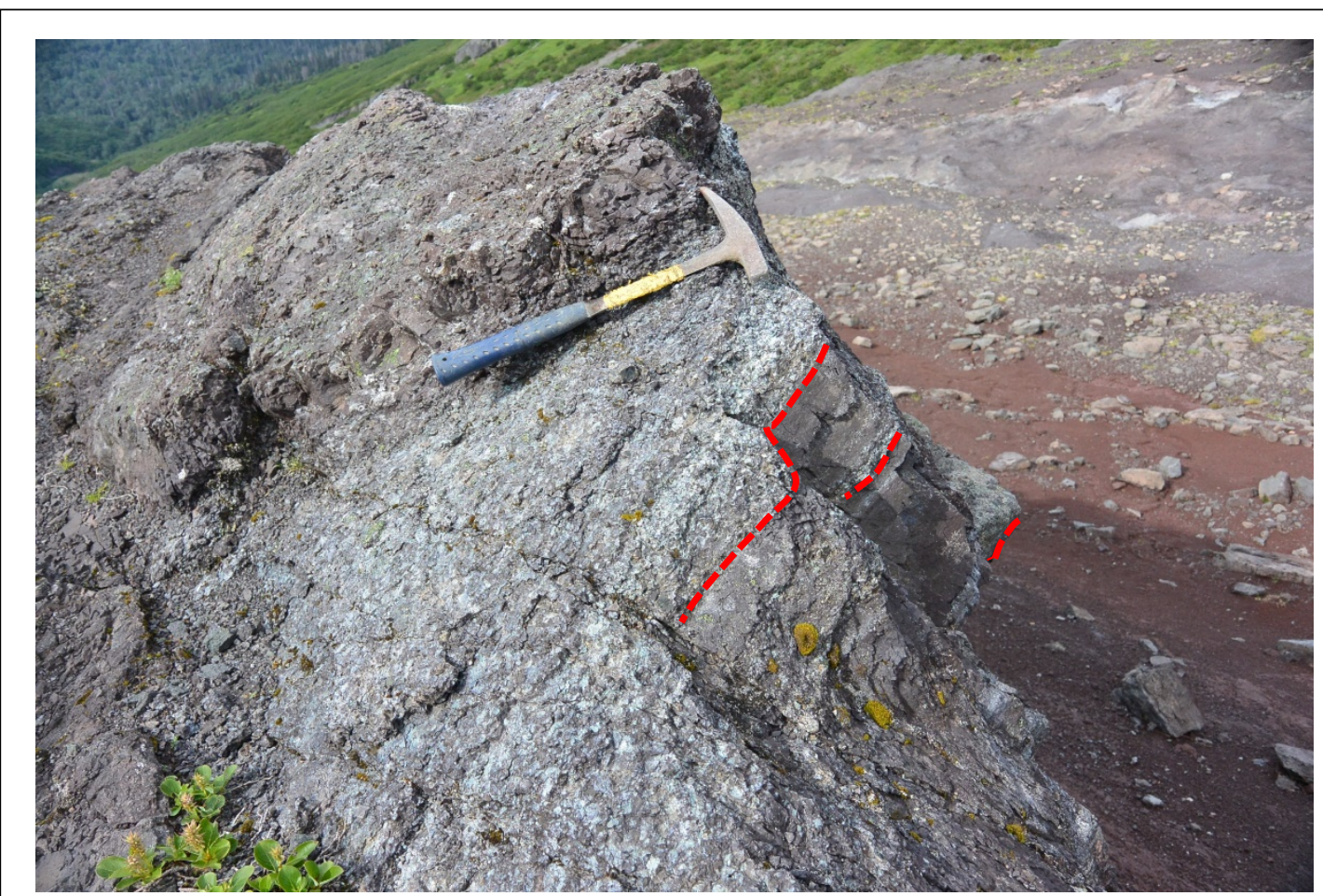

Figure 2-6a.

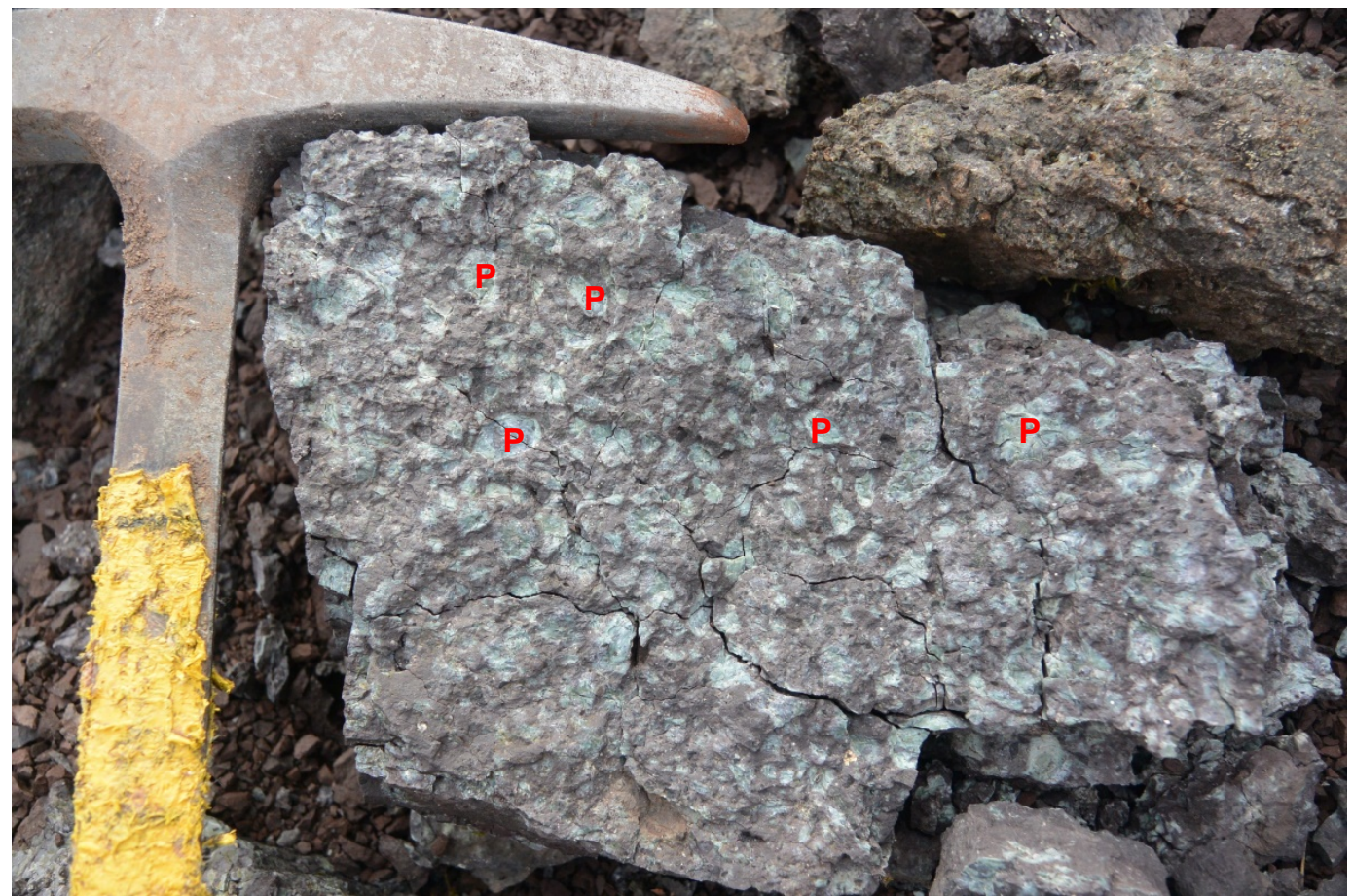

Figure 2-6b.

Figure 2-6. Selected photographs showing key features in conglomerates from the study area. $\boldsymbol{a}$. Multiple thin beds of pumice clast pebble conglomerate. Rock hammer is $42 \mathrm{~cm}$ long. b. Pumice clast pebble conglomerate from the bed shown in figure 2-6a is positioned immediately below rock hammer. Pumice clasts are pistachio green and have altered to clay. Selected pumice clasts are marked with red letter P. Visible part of rock hammer is $17 \mathrm{~cm} l o n g$. 


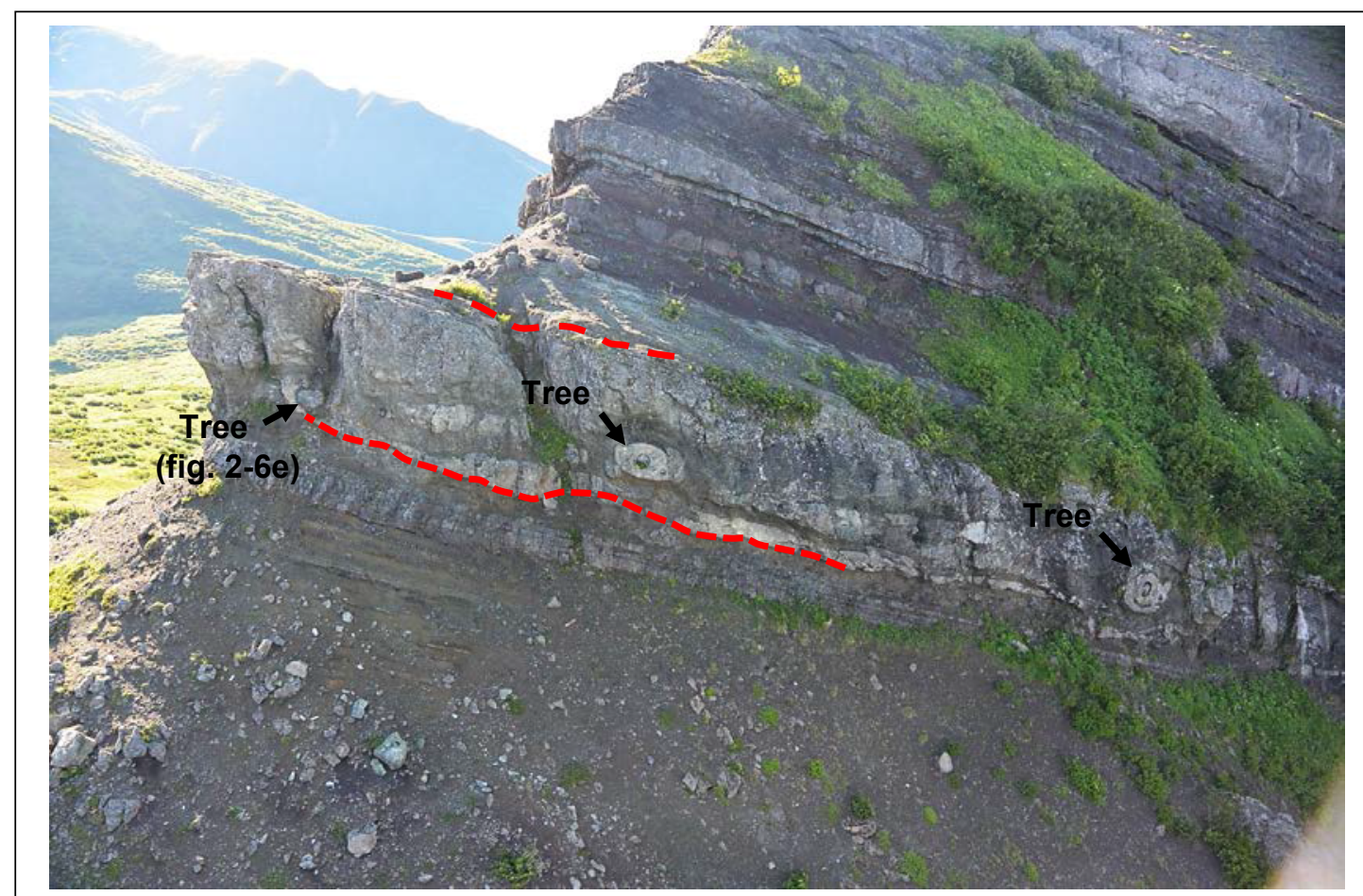

Figure 2-6c.

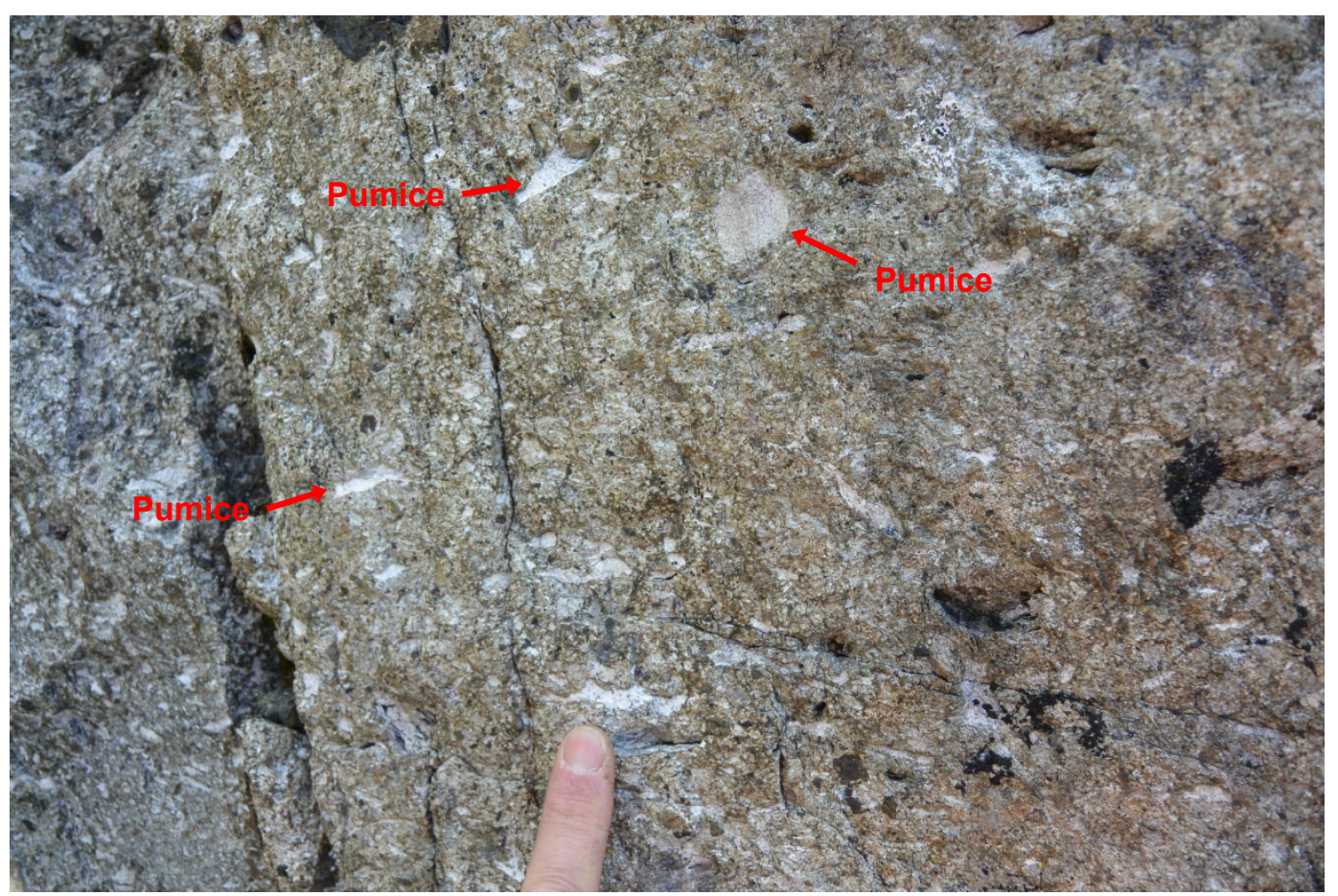

Figure 2-6d.

Figure 2-6 (cont.). Selected photographs showing key features in conglomerates from the study area. c. Thick pumice clast conglomerate bed at the top of the measured section. Note the trees in the lower part of the bed. Tree-bearing conglomerate bed is more than $4 \mathrm{~m}$ thick, for sense of scale. Photograph taken from helicopter, with view toward southeast. $\boldsymbol{d}$. Close-up view of pumice clasts in the bed shown in figure 2-6c. 


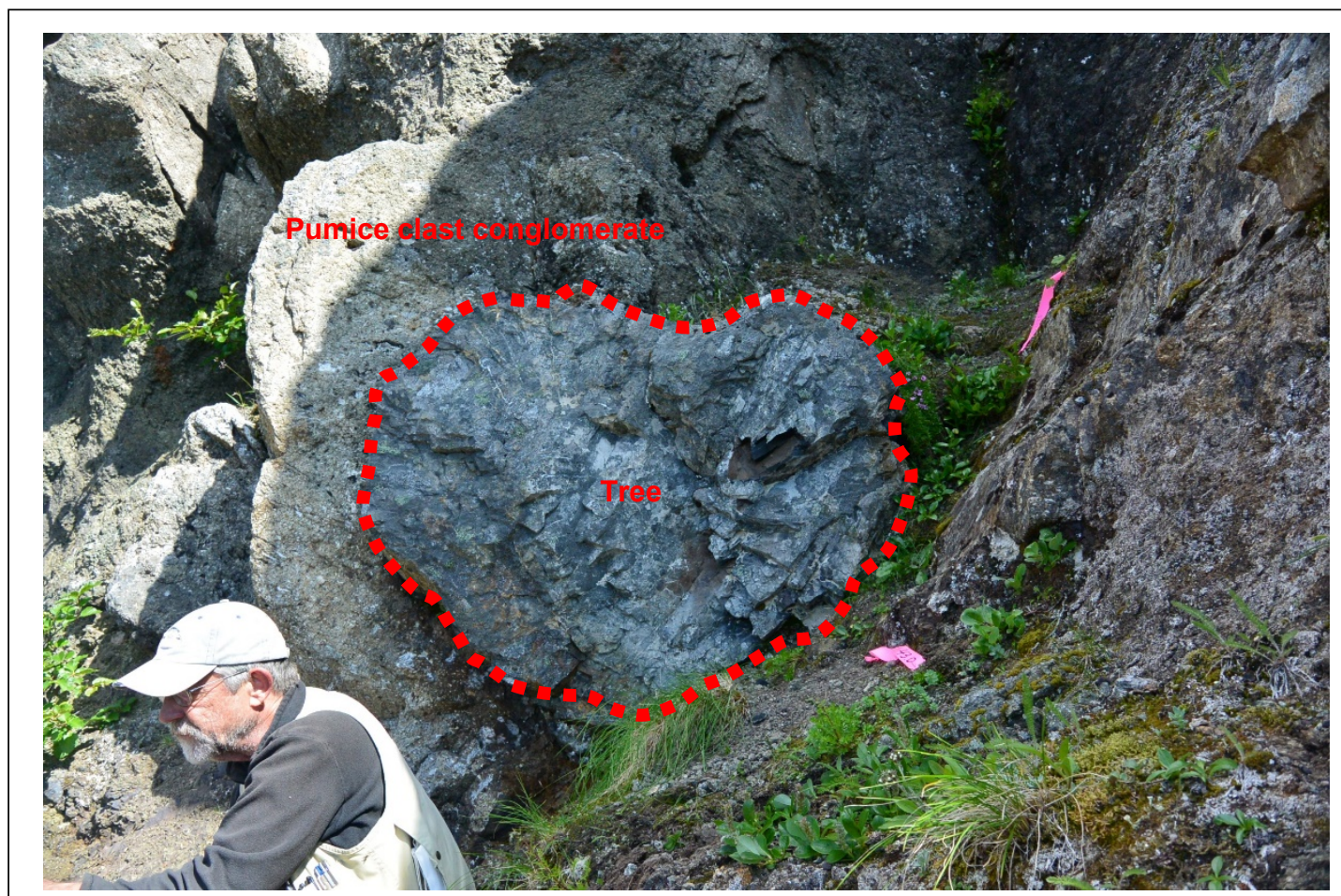

Figure 2-6e.

Figure 2-6 (cont.). Selected photographs showing key features in conglomerates from the study area. e. Transverse cross-sectional view of large log in the bed shown in figure 2-6c. Maximum diameter of log is $1.5 \mathrm{~m}$; larger diameter logs are visible in figure 2-6c.

\section{ACKNOWLEDGMENTS}

We gratefully acknowledge Kate Bull for showing us the exposure at Horn Mountain during the 2014 field season. Funding for the Alaska DNR Cook Inlet basin analysis program was provided by the State of Alaska, with additional support from Apache Corporation and the U.S. Geological Survey's National Cooperative Geologic Mapping Program through STATEMAP under award numbers G13AC00157 and G15AC00199. We gratefully acknowledge the following organizations for granting land access: Lake Clark National Park \& Preserve; Cook Inlet Region, Inc.; and Chickaloon, Knik, Ninilchik, Salamatof, Seldovia, and Tyonek Native village corporations. Merlin "Spanky" Handley provided helicopter transportation for the DNR field crew during the 2015 season. We thank the owners and staff of the Snug Harbor Wilderness Lodge on Chisik Island for their hospitality. We thank Trystan Herriott and Nina Harun for their thorough technical reviews of the manuscript. We thank the 2015 DNR Red Glacier-Iliamna bedrock mapping crew for valuable discussions in the field.

\section{REFERENCES CITED}

Bull, K.F., 2015, Preliminary observations - Continued facies analysis of the Lower Jurassic Talkeetna Formation, north Chinitna Bay, Alaska, in Wartes, M.A., ed., Energy-related studies during the 2014 field season, western Cook Inlet, Alaska: Alaska Division of Geological \& Geophysical Surveys Preliminary Interpretive Report 2015-5-4, p. 15-22. doi: $\underline{10.14509 / 29459}$

Detterman, R.L., and Hartsock, J.K., 1966, Geology of the Iniskin-Tuxedni Region, Alaska: U.S. Geological Survey Professional Paper 512, 78 p., 6 sheets, scale 1:63,360.

Knowlton, F.H., 1916, A Lower Jurassic flora from the upper Matanuska Valley, Alaska: Proceedings of the U.S. National Museum, v. 51, no. 2158, p. 451-460, four plates. 